\title{
Prescribed Burning Has Limited Long-Term Effectiveness in Controlling Trembling Aspen (Populus tremuloides) Encroachment into Fescue Grassland in Prince Albert National Park
}

\author{
Digit D. Guedo and ERIC G. LAMB ${ }^{1}$
}

Department of Plant Sciences, University of Saskatchewan, 51 Campus Drive, Saskatoon, Saskatchewan S7N 5A8 Canada

${ }^{1}$ Corresponding author; email: eric.lamb@usask.ca

Guedo, Digit D., and Eric G. Lamb. 2013. Prescribed burning has limited long-term effectiveness in controlling Trembling Aspen (Populus tremuloides) encroachment into fescue grassland in Prince Albert National Park. Canadian FieldNaturalist 127(1): 50-56.

Encroachment into grassland by woody species is a global ecological phenomenon, and it is of particular concern in remnant fescue (Festuca) prairie at the aspen parkland-boreal forest ecotone. Fire suppression is thought to encourage encroachment; however, prescribed burning as a means of controlling encroachment and restoring system structure, function, and composition has had variable success. The objective of this study was to determine the effects of different season of burn, number of annual burns, and number of years after burning treatments on Trembling Aspen (Populus tremuloides) encroachment into the fescue grasslands within Prince Albert National Park, Saskatchewan. Temporal changes in density and cover of Trembling Aspen in grassland and grassland-forest transition plant communities were evaluated using data from a prescribed burn study conducted in Prince Albert National Park from 1975 to 2010. The effect of year (indicating varying amounts of time relative to prescribed burning) and the interaction between spring burning and year reflect a stimulatory effect of burning on Trembling Aspen suckering. Increased Trembling Aspen cover in the forest transition community with more annual burns, burning in the fall, and the interaction between year and number of annual burns and increased Trembling Aspen cover in the grassland community with year indicate that none of the treatments had lasting control of Trembling Aspen encroachment. Ongoing Trembling Aspen encroachment despite prescribed burning may be due to important missing interactions between fire and grazing. A change in the use and expectation of prescribed burning is needed when attempting to suppress Trembling Aspen encroachment into the fescue grasslands.

Key Words: encroachment, fescue prairie, fire suppression, grassland, Trembling Aspen, Populus tremuloides, prescribed burning, succession, Prince Albert National Park of Canada, Saskatchewan.

Encroachment of woody species is a significant ecological management issue on a global scale, particularly in moist grasslands such as the Northern Great Plains (Moss and Campbell 1947; Maini 1960; Bailey and Wroe 1974). Species such as Trembling Aspen (Populus tremuloides) can threaten habitat and biodiversity through a reduction in grassland area, isolation and fragmentation of patches, and reduced connectivity and genetic flow between patches (Fu et al. 2008).

As a result of agriculture and urbanization, only $6 \%$ of the historical extent of the fescue (Festuca) prairie remains in Saskatchewan, Canada, and much of that is small remnant patches less than 65 ha in size (Gerry and Andersen 2002*). In addition to the loss of area, the natural historical fire regimes that are thought to have controlled encroachment by woody species into grassland have been altered. In the fescue grasslands found in Prince Albert National Park of Canada, the historical $15-40$ year fire return interval is now greatly exceeded due to factors that include fire suppression and the low probability of large-scale fires in what is now a largely agricultural landscape (Weir 1996). Although the fescue grasslands in Prince Albert National Park constitute only a fraction of the remaining fescue prairie in Saskatchewan, they are of particular conservation interest, and effective strategies to control encroachment into these and other grasslands is urgently needed (Gerry and Andersen 2002*; Fu et al. 2008; Parks Canada 2012*).

Encroachment by woody species into grasslands is controlled by interactions between climate, fire, and herbivory (Bailey and Wroe 1974; Campbell et al. 1994; Bork et al. 1997; Ripley and Archibold 1999; Hogg et al. 2008; Michaelian et al. 2010). Although prescribed burning is widely used to address encroachment and to restore grasslands by mimicking natural disturbance, effectiveness in suppressing Trembling Aspen varies with the treatments used and the site conditions (Pylypec and Romo 2003; Romo 2003).

It is important to determine how encroachment in a given area is affected by prescribed burn treatments, such as the number and the season of burns, to better focus efforts to control encroachment by woody species. An investigation of the long-term effectiveness of prescribed burning is also needed to determine whether, and for how long, encroachment is suppressed.

To determine the effectiveness of number of annual burns and season of burning in controlling encroachment by Trembling Aspen over time, we examined tree density and cover in the fescue grasslands of Prince Albert National Park. We examined the effects of three, four, and five annual burns within an eight-year period, 
and we examined the effects of burning in the spring and fall. We used a 36-year dataset allowing comparisons of 1975 pre-burn, 1983 post-burn, 1995 burn recovery, and 2010 burn recovery to assess how the density and cover of Trembling Aspen changed over time with different prescribed burn treatments.

Increases in Trembling Aspen cover over time indicate that none of the prescribed burn treatments implemented in this study suppressed Trembling Aspen encroachment over the long term.

\section{Methods}

Study area

The study area is located in the southwestern portion of Prince Albert National Park $\left(53^{\circ} 36^{\prime} \mathrm{N}, 106^{\circ} 31^{\prime} \mathrm{W}\right)$, approximately $50 \mathrm{~km}$ northwest of Prince Albert, Saskatchewan. The study area lies within the Boreal Transition Ecoregion, but patches characteristic of the more southern Aspen Parkland Ecoregion are common (Acton et al. 1998; Parks Canada 2012*). The Aspen Parkland Ecoregion is characterized by forest dominated by Trembling Aspen interspersed with patches of fescue grassland.

Three areas of fescue grassland in Prince Albert National Park were utilized during this study: Wasstrom's Flats, Sugar Creek, and Rabbit Creek. The grassland in these areas is dominated by Plains Rough Fescue (Festuca hallii) and Slender Wheatgrass (Elymus trachycaulus ssp. subsecundus), while forest transition areas surrounding the grassland and in isolated pockets within the grasslands are dominated by Trembling Aspen.

An average of $452 \mathrm{~mm}$ of precipitation falls on the site annually, $329 \mathrm{~mm}$ as rainfall and $123 \mathrm{~mm}$ as snowfall (Environment Canada 2011*). Soils are Orthic Black Chernozems occurring on coarse to moderately coarse textured glaciofluvial deposits (Padbury et al. 1978*). Current disturbances in the study area include intermittent grazing by Plains Bison (Bison bison bison) and North American Elk (Cervus elaphus) and occasional recreational use by park visitors. Other anthropogenic influences include a vehicle trail and ploughed firebreaks that bisect the sites.

\section{Study design and data collection}

We examined the effect of prescribed annual burning on Trembling Aspen density and cover in open grassland and grassland-forest transition (forest transition) communities using a 36-year (1975-2010) dataset collected from permanently marked plots (Gunn et al. 1976*; Trottier 1985; Kenkel 2002*). All data used in this study are archived in the appendices to Guedo (2012).

The site was initially surveyed in 1975 , approximately 28 years after the previous known fire. Burn treatments included season of burn (spring or fall) and number of annual burns (three, four, or five) that were applied between 1976 and 1982 in an incomplete factorial design (only the four-burn treatment was con- ducted in the spring) (Table 1). Observational descriptions of the treatment areas and prescribed burns are provided in Gunn et al. (1976*) and Trottier (1985). Follow-up data were collected from surveys in 1983, 1995, and 2010. The resulting dataset captures Trembling Aspen density and cover prior to burning in 1975, in 1983 after all burning treatments were carried out, in 1995 after a moderate length of recovery after burning, and in 2010 after a longer length of recovery after burning.

Prescribed burns separate from the current study were conducted on the Sugar Creek site in 2006 and 2009. As density and cover data collected from the 2010 Sugar Creek survey would not reflect the original study design, the 2010 Sugar Creek data were excluded from the analysis.

Sampling was conducted in 20 plots -11 in the forest transition community and 9 in the grassland community (Table 1). The forest transition and grassland plant communities were subjectively defined by field observation at the beginning of the study in 1975 . The forest transition plant community was defined as locations where Trembling Aspen encroachment was evident, given Trembling Aspen recruitment along the grassland-forest ecotone. The grassland community was defined by open areas free of Trembling Aspen encroachment. Each plot contained 25 permanent quadrats marked by a metal stake laid out in a square grid (Guedo and Lamb 2013).

For plots within the forest transition community, a $2-\mathrm{m}^{2}$ quadrat was used to collect density data by enumerating stems of Trembling Aspen.

In both the forest transition and grassland community plots, a $1-\mathrm{m}^{2}$ quadrat was used to collect canopy cover data for Trembling Aspen (Guedo 2012). Cover classes of Trembling Aspen $(1=1-10 \%, 2=11-20 \%$ $\ldots 10=91-100 \%$ ) were recorded in the $1-\mathrm{m}^{2}$ quadrats in 1975,1983 , and 1995. Percentage cover data were recorded in 2010 and converted to cover class, for uniform treatment of data from all survey years.

Mid-point averages of each cover class $(1=5 \%, 2=$ $15 \% \ldots 10=95 \%$ ) were calculated, and mean species cover for each plot was used in the cover analysis. Similarly, mean stem density in each plot was used in the density analysis. As plots were specifically set up to monitor change in Trembling Aspen cover and density over time under different prescribed burning treatments, plots were the experimental unit in this study.

\section{Statistical analysis}

The effects of the number of burns, season of burning, and time since burning on Trembling Aspen density were determined using generalized linear mixed models fitted with a Poisson distribution. This approach was taken, as a Poisson distribution is most appropriate for count data (this study assessed number of Trembling Aspen stems under the different burn treatments) (Crawley 2007). 
TABle 1. Prescribed burn treatment combinations used in the Prince Albert National Park of Canada prescribed burn study, 1975-2010. Grassland areas include Wasstrom's Flats, Rabbit Creek, and Sugar Creek. Plots were set out in grassland and forest transition plant communities (grassland-Trembling Aspen forest ecotone where Trembling Aspen encroachment was evident in 1975). Plot numbers identify treatment replications within each community type and indicate the number of plots subjected to different treatment combinations applied between 1975 and 1982: season of burning (fall or spring) and number of annual burns (three, four or five). No grassland plots were established in the Rabbit Creek grassland.

\begin{tabular}{|c|c|c|c|c|}
\hline $\begin{array}{c}\text { No. of } \\
\text { grassland } \\
\text { plots }\end{array}$ & $\begin{array}{c}\text { No. of } \\
\text { forest transition } \\
\text { plots }\end{array}$ & $\begin{array}{c}\text { Season of } \\
\text { prescribed } \\
\text { burning }\end{array}$ & $\begin{array}{c}\text { No. of } \\
\text { prescribed } \\
\text { annual burns }\end{array}$ & Year of prescribed burning \\
\hline \multicolumn{5}{|c|}{ Wasstrom's Flats } \\
\hline 2 & 2 & Fall & 3 & $1975,1979,1980$ \\
\hline 2 & 2 & Fall & 5 & $1975,1976,1979,1980,1981$ \\
\hline 4 & 4 & Spring & 4 & $1976,1977,1981,1982$ \\
\hline \multicolumn{5}{|c|}{ Rabbit Creek } \\
\hline 0 & 1 & Fall & 4 & $1975,1976,1980,1981$ \\
\hline 0 & 1 & Spring & 4 & $1976,1977,1981,1982$ \\
\hline \multicolumn{5}{|c|}{ Sugar Creek } \\
\hline 1 & 1 & Fall & 4 & $1975,1976,1980,1981$ \\
\hline 1 & 1 & Spring & 4 & $1976,1977,1981,1982$ \\
\hline
\end{tabular}

The effects of the burn treatments on Trembling Aspen cover were analyzed using general linear models, as the cover class data used in the analysis were the mean quadrat cover in each plot, and were thus presumed to follow a normal distribution. A mixed model approach was used to address the non-independence of samples arising through repeated surveys of plots and the nesting of plots within the different grassland areas.

All analyses were conducted using linear mixedeffects models (lmer and lme functions) in the R.2.12.1 package (R Development Core Team 2011).

Model selection procedures (Crawley 2007) were used where a maximal model containing all possible treatments and treatment combinations was reduced by grouping non-significantly different treatments and removing non-significant model terms (Crawley 2007). If a new model with combined treatments or removed terms resulted in a non-significant drop in Akaike's Information Criterion (AIC) and in variance explained $(\mathrm{P} \geq 0.05)$ from the previous model, it was retained and further simplified if possible. The minimally adequate (best) model was then compared to a null model containing only the random terms.

A significant difference between the null and minimally adequate (best) model $(P<0.05)$ confirmed that the fixed factors including burn treatment combinations retained in the minimally adequate (best) model represented significant differences in Trembling Aspen density or cover. Using this model selection approach is particularly powerful in studies with complex experimental design and relatively small sample sizes, as combining and removing non-significant treatment effects permits a more powerful test of the remaining model terms (Crawley 2007).

Three separate models were generated: one for Trembling Aspen density in the forest transition community, one for Trembling Aspen cover in the forest transition community, and one for Trembling Aspen cover in the grassland community. A model for Trembling Aspen density in the grassland community was not possible, as the initial study design did not collect data on the density of woody species in the grassland plots, presumably because the presence of Trembling Aspen in the grassland was negligible when the plots were established. The maximal models for Trembling Aspen density and Trembling Aspen cover in the forest transition community included year, season, and number of annual burns as main effects, and the interactions between year and season and between year and the number of annual burns.

No grassland plots were established in the Rabbit Creek site due to its small size, providing only a single replicate of the four annual burns in the fall treatment combination in the grassland community. Having only one replicate of this treatment combination in the grassland community would likely cause spurious results for that treatment interaction; thus the maximal model for the grassland plant community included only the year, season, and number of annual burns. As spring treatment plots were burned only four times, the incomplete factorial design precluded testing the interaction between the season and number of annual burns in all models.

In all models, the year main effect is simply change in Trembling Aspen density or cover over time, shown through the year in which sampling occurred: in 1975 prior to burning, or in 1983, 1995, or 2010 with varying amounts of time after the prescribed burn treatments were applied between 1975 and 1982. The interaction between year and season indicates how Trembling Aspen cover or density changed over time with burning in either fall or spring, and the interaction between year and number of annual burns indicates how Trembling Aspen cover or density changed over time with either three, four, or five annual burns being used. 
Random factors for all analyses included plot and grassland area, with plots nested within grassland areas. Random factors were specified to address the nonindependence of samples arising through repeated measures of plots and the nesting of plots within the different grassland areas.

\section{Results}

Trembling Aspen density in the forest transition community was significantly affected by year and the year-season interaction but was not affected by the number of annual burns (Figure 1). The best Trembling Aspen density model included year with 1975 and 1995 combined, season, and the year-season interaction (maximal vs. best model $\chi_{8}^{2}=13.18, P=0.214$ ). Trembling Aspen density was significantly lower in $2010\left(0.8 \mathrm{~m}^{-2}\right)$ than in $1983\left(3.3 \mathrm{~m}^{-2}, z=-3.84, P<\right.$ $0.001)$. There was a year-season interaction, as density in plots burned in spring was $1.5 \mathrm{~m}^{-2}$ in 1975-1995 and $4.3 \mathrm{~m}^{-2}$ in 1983 , while the density in plots burned in fall was $2.0 \mathrm{~m}^{-2}$ and $2.4 \mathrm{~m}^{-2}$ over the same period $(z=-3.98, P<0.001)$.

Cover of Trembling Aspen in the forest transition community was significantly affected by number of annual burns, season, and the interaction between year and the number of annual burns (Figure 1). The best model for Trembling Aspen cover in the forest transition community included year $(1975,1983$, and 1995 combined), season, number of annual burns, the yearnumber of annual burns interaction, and the year-season of burn interaction (maximal model vs. best model $\left.F_{11,19}=12.75, P=0.121\right)$. The year-season interaction was not statistically significant; however, it was retained in the model, as its removal reduced the variance explained between models (previous minimally adequate model vs. model with year-season interaction removed $F_{10,11}=3.66, P=0.056$ ).

Trembling Aspen cover in the forest transition community was greater with four annual burns $(11.4 \%$ $\left.\mathrm{m}^{-2}, t=5.21, P=0.002\right)$ and five annual burns $(13.7 \%$ $\left.\mathrm{m}^{-2}, t=2.48, P=0.048\right)$ than with three annual burns $\left(9.4 \% \mathrm{~m}^{-2}\right)$. Plots with spring burns had less Trembling Aspen cover $\left(10.7 \% \mathrm{~m}^{-2}\right)$ than plots with fall burns $\left(12.1 \% \mathrm{~m}^{-2}, t=-2.51, P=0.046\right)$. Cover increased through time with burns, as shown by the year-number of annual burns interaction: a) plots with four annual burns had $4.9 \% \mathrm{~m}^{-2}$ Trembling Aspen cover in 1975, 1983, and 1995 and $37 \% \mathrm{~m}^{-2}$ in $2010(t=-4.94, P<$ 0.001 ), and b) plots with five annual burns had $8.8 \%$ Trembling Aspen cover in 1975, 1983, and 1995 and $28.4 \%$ in $2010(t=-2.08, P=0.046)$. The year-season interaction shows plots burned in the fall had $8.0 \%$ $\mathrm{m}^{-2}$ Trembling Aspen cover in 1975, 1983, and 1995 and $27.0 \% \mathrm{~m}^{-2}$ in 2010 , while plots burned in the spring had $4.0 \% \mathrm{~m}^{-2}$ Trembling Aspen cover in 1975, 1983, and 1995 and $34.7 \% \mathrm{~m}^{-2}$ Trembling Aspen cover in $2010(t=1.83, P=0.077)$.
Cover of Trembling Aspen in the grassland community was significantly affected by year, but not by season or the number of annual burns (Figure 1). The best model for Trembling Aspen cover in the grassland community included year $(1975,1983$, and 1995 combined) (maximal model vs. best $\operatorname{model} F_{5,10}=2.58$, $P=0.764$ ). Trembling Aspen cover in the grassland increased significantly between 1975, 1983, and 1995 $\left(1.5 \% \mathrm{~m}^{-2}\right)$ and $2010\left(4.0 \% \mathrm{~m}^{-2}, t=-4.45, P<0.001\right)$.

\section{Discussion}

Managing woody species encroachment is critical in maintaining grassland; this study demonstrates that relying on a short series of prescribed fires alone can be ineffective. This response is not entirely unexpected, as the use of prescribed burning as a means of controlling encroachment has had negligible results in other grasslands in the Northern Great Plains (Heisler et al. 2003; Heisler et al. 2004; Briggs et al. 2005) and the burning treatments used at this site had limited effects on the frequency and abundance of forest understory species (Guedo and Lamb 2013). Infrequent fire in other areas of the fescue prairie can also lead to increased encroachment by Trembling Aspen, Bog Birch (Betula pumila), and willow (Salix) species (Bailey et al. 1990; Bork et al. 1997; Bork and Burkinshaw 2009).

The failure of a short series of prescribed burns to suppress encroachment over the long term may be explained by the stimulatory effect fire can have on Trembling Aspen. Control of regrowth after burning requires a secondary form of suppression. If suckering is left unchecked, Trembling Aspen can colonize and dominate disturbed sites (Maini 1960; Schier 1973; Mueggler 1989; Keyser et al. 2005). Increased soil water content and temperature after fire are considered important factors in sucker initiation, facilitating growth earlier in the spring and providing a longer growing season. Increased soil water content and temperature are also thought to promote auxin degradation and cytokinin synthesis (Johnston 1981; Hungerford 1988*; Fraser et al. 2002). The increased density observed in 1983 in Prince Albert National Park with spring burning agrees with these findings, as soil temperatures likely increased earlier in the season with spring burning than with fall burning.

Cover of Trembling Aspen may also increase with time after burning as a result of the growth of suckers and the recovery of mature trees in the overstory. With this increase in growth, however, low light intensities may negatively affect growth of individual Trembling Aspen suckers (Farmer 1963). Inter- and intraspecific competition for light and other resources promotes selfthinning, as evidenced here by a reduction in density coinciding with an increase in overall cover of Trembling Aspen over time following burning.

Self-thinning of new stems may be accelerated with spring burning, as we found that density was initially 

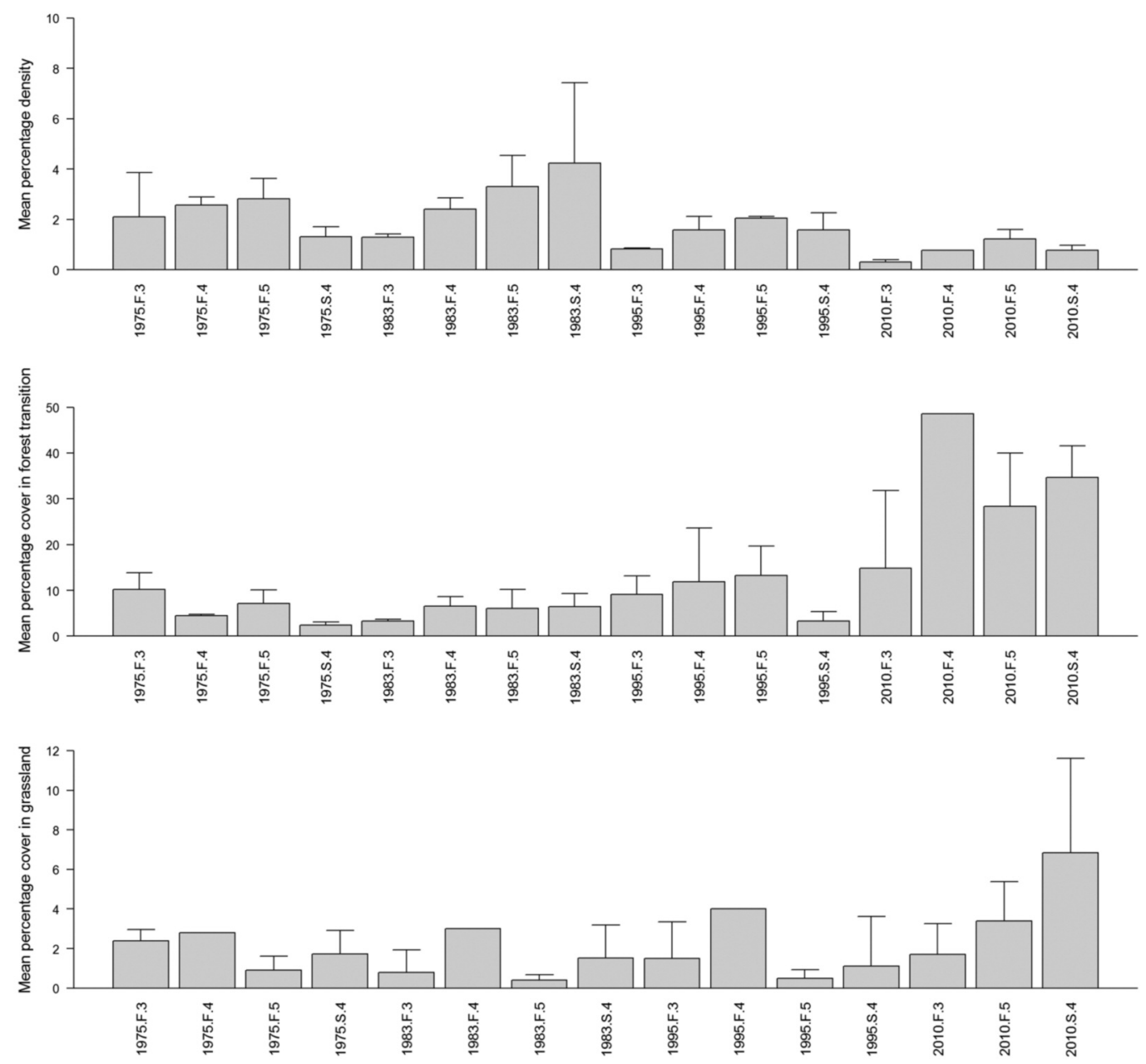

Figure 1. Mean Trembling Aspen (Populus tremuloides) density (stems $\mathrm{m}^{-2}$ ) in the forest transition community, mean Trembling Aspen percentage cover in the forest transition community, and mean Trembling Aspen percentage cover in the grassland community with the prescribed burn treatments applied during the prescribed burn study in Prince Albert National Park of Canada, 1975-2010. Treatments codes on the $x$ axis indicate year of sampling (1975, 1983, 1995 , and 2010), season of burning ( $\mathrm{F}=$ fall, $\mathrm{S}=\mathrm{spring}$ ), and number of annual burns (three, four, and five). Error bars are one standard deviation. The four fall burn treatments had only one replicate in 2010 for density and cover in the forest transition, and thus do not have error bars. The four fall burn treatments had only one replicate in 1975, 1983, and 1995 for cover in the grassland, and thus do not have errors bars. There was no treatment with four fall burns in the grassland in 2010. Due to the complexity of the interactions in the models, letters indicating significance of fixed effects are not shown.

higher in plots that were burned in the spring, where competition for light and resources would subsequently be more intense (Hendrickson 1988). Increased competition in plots burned in the spring as a result of greater sucker density may also explain why less cover was observed over time in plots burned in the spring than in plots burned in the fall in the forest transition community.

Trembling Aspen recovery depends on stored resources after disturbance, and frequency of disturbance is important in determining suckering at the community level (Bellingham and Sparrow 2000). If Trembling Aspen recovered between burn events, suckering might have been stimulated more frequently on plots burned four and five times than on plots burned three times. This increase in suckering may explain why cover was greater with four and five annual burns in the forest transition community. With no initial Trembling Aspen overstory in the grassland community, post-burn Trembling Aspen growth was likely less limited by lack of 
light, and this may explain the increase in Trembling Aspen cover over time in this community (Huffman et al. 1999).

Application of three to five prescribed fires alone over a period of three to seven years has clearly not been effective in controlling Trembling Aspen encroachment into the fescue grasslands of Prince Albert National Park. In addition, increases in Trembling Aspen cover occurred despite using prescribed burn treatments set within the historical fire return interval. Controlling Trembling Aspen encroachment is much more complex than using fire on Trembling Aspen alone, and it likely involves successional pathways, including interactions of climate, fire, grazing, and possibly behavioural interactions between grazers and predators (Knapp and Seastedt 1986; Campbell et al. 1994; Hogg et al. 2008; Fuhlendorf et al. 2009; Michaelian et al. 2010; Seager et al., in press).

In the fescue grasslands of Prince Albert National Park, integrated management practices such as increased fire frequency and grazing after burning are likely needed to address suckering and to prevent recovery of Trembling Aspen after fire (Bailey et al. 1990; Bork et al. 1996; Heisler et al. 2004; Bork and Burkinshaw 2009). Opportunities exist in Prince Albert National Park to mimic natural disturbance regimes, such as interactions of fire and grazing. Relying on prescribed burning alone using treatments such as those included in this study is not likely to be effective in controlling Trembling Aspen.

\section{Acknowledgements}

We thank L. Carbyn, G. Trottier, M. Vetter, J. Wilmshurst, and those involved in the collection of data. Prince Albert National Park of Canada and staff, including H. McPhee, G. Rutten, T. Stene, L. Thorpe, and J. Weir, provided logistical support, and A. Guy assisted in the field. Financial support was provided by a Discovery grant from the Natural Sciences and Engineering Research Council and a Canadian Foundation for Innovation grant to EGL and a College of Graduate Studies scholarship to DDG.

Documents Cited (marked * in text)

Environment Canada. 2011. National Climate Data and Information Archive, Environment Canada. http://www .climate.weatheroffice.gc.ca. (Accessed 24 June 2011).

Gerry, A., and M. Andersen. 2002. Distribution of fescue grassland across Saskatchewan: a predictive modelling approach. Fish and Wildlife Branch, Saskatchewan Environment, Regina, Saskatchewan.

Gunn, A., G. W. Scotter, D. Sept, and L. Carbyn. 1976. Prescribed controlled burn study of fescue grasslands in Prince Albert National Park. Progress Report No. 1. Edmonton, Alberta.

Hungerford, R. D. 1988. Soil temperatures and suckering in burned and unburned aspen stands in Idaho. U.S. Department of Agriculture, Forest Service, Intermountain Research Station. Research Note INT-378.
Kenkel, N. 2002. Prescribed burning and tree encroachment in Prince Albert National Park fescue grasslands. Western Canada Service Centre, Parks Canada, Winnipeg, Manitoba.

Padbury, G.A., W. K. Head, and W. E. Souster. 1978. Biophysical resource inventory of the Prince Albert National Park, Saskatchewan. Saskatchewan Institute of Pedology Publication S185. Saskatoon, Saskatchewan.

Parks Canada. 2012. Prince Albert National Park Fescue Management Plan. Prince Albert National Park, Saskatchewan.

\section{Literature Cited}

Acton, D. F., G. A. Padbury, and C. T. Stushnoff. 1998. The Ecoregions of Saskatchewan. Canadian Plains Research Center, Regina, Saskatchewan.

Bailey, A. W., and R. A. Wroe. 1974. Regeneration of woody species following burning and grazing in Aspen Parkland. Journal of Range Management 31: 466-449.

Bailey, A. W., B. D. Irving, and R. D. Fitzgerald. 1990. Regeneration of woody species following burning and grazing in Aspen Parkland. Journal of Range Management 43: 212-215.

Bellingham, P. J., and A. D. Sparrow. 2000. Resprouting as a life history strategy in woody plant communities. Oikos 89: 409-416.

Bork, E. W., and A. M. Burkinshaw. 2009. Cool-season floodplain meadow responses to shrub encroachment in Alberta. Rangeland Ecology \& Management 62: 44-52.

Bork, E., D. Smith, and M. Willoughby. 1996. Prescribed burning of bog birch. Rangelands 18: 4-7.

Bork, E. W., R. J. Hudson, and A. W. Bailey. 1997. Populus forest characterization in Elk Island National Park relative to herbivory, prescribed fire, and topography. Canadian Journal of Botany 75: 1518-1526.

Briggs, J. M., A. K. Knapp, J. M. Blair, J. L. Heisler, G. A. Hoch, M. S. Lett, and J. K. McCarron. 2005. An ecosystem in transition: causes and consequences of the conversion of mesic grassland to shrubland. BioScience 55: 243-254.

Burkinshaw, A., and E. Bork. 2009. Shrub encroachment impacts the potential for multiple use conflicts on public land. Environmental Management 44: 493-504.

Campbell, C., I. D. Campbell, C. B. Blyth, and J. H. McAndrews. 1994. Bison extirpation may have caused Aspen expansion in Western Canada. Ecography 17: 360362.

Crawley, M. J. 2007. The R Book. John Wiley \& Sons, Chichester, U.K.

Farmer, R. E., Jr. 1963. Effect of light intensity on growth of Populus tremuloides cuttings under two temperature regimes. Ecology 44: 409-411.

Fraser, E. C., V. J. Lieffers, S. M. Landhäusser, and B. R. Frey. 2002. Soil nutrition and temperature as drivers of root suckering in trembling aspen. Canadian Journal of Forest Research 32: 1685-1691.

Fu, Y., J. Qui, and J. F. Wilmshurst. 2008. Interpolating genetic variation in natural populations: a case study of plains rough fescue (Festuca hallii). Open Evolution Journal 2: $31-40$.

Fuhlendorf, S. D., D. M. Engle, J. A. Y. Kerby, and R. Hamilton. 2009. Pyric herbivory: rewilding landscapes through the recoupling of fire and grazing. Conservation Biology 23: 588-598. 
Guedo, D. D. 2012. Long-term changes in abundanceoccupancy relationships and trembling aspen cover and density with prescribed burning in the fescue grasslands of Prince Albert National Park. M.Sc. thesis, University of Saskatchewan, Saskatoon, Saskatchewan.

Guedo, D. D., and E. G. Lamb. 2013. Temporal changes in abundance-occupancy relationships within and between communities after disturbance. Journal of Vegetation Science 24: 607-615.

Heisler, J. L., J. M. Briggs, and A. K. Knapp. 2003. Longterm patterns of shrub expansion in $\mathrm{a}_{4}$-dominated grassland: fire frequency and the dynamics of shrub cover and abundance. American Journal of Botany 90: 423-428.

Heisler, J. L., J. M. Briggs, A. K. Knapp, J. M. Blair, and A. Seery. 2004. Direct and indirect effects of fire on shrub density and aboveground productivity in a mesic grassland. Ecology 85: 2245-2257.

Hendrickson, O. Q. 1988. Biomass and nutrients in regenerating woody vegetation following whole-tree and conventional harvest in a northern mixed forest. Canadian Journal of Forest Research 18: 1427-1436.

Hogg, E. H. J. P. Brandt, and M. Michaelian. 2008. Impacts of a regional drought on the productivity, dieback, and biomass of western Canadian aspen forests. Canadian Journal of Forest Research 38: 1373-1384.

Huffman, R. D., M. A. Fajvan, and P. B. Wood. 1999. Effects of residual overstory on aspen development in Minnesota. Canadian Journal of Forest Research 29: 284-289.

Johnston, M. 1981. The effect of fire disturbance level on plant re-establishment in Elk Island National Park, Alberta. M.Sc. thesis, University of Alberta, Edmonton, Alberta.

Keyser, T. L., F. W. Smith, and W. D. Shepperd. 2005. Trembling aspen response to a mixed-severity wildfire in the Black Hills, South Dakota, USA. Canadian Journal of Forest Research 35: 2679-2684.

Knapp, A. K., and T. R. Seastedt. 1986. Detritus accumulation limits productivity of tallgrass prairie. BioScience 36: $662-668$.
Maini, J. S. 1960. Invasion of grassland by Populus tremuloides in the Northern Great Plains. Ph.D. thesis, University of Saskatchewan, Saskatoon, Saskatchewan.

Michaelian, M., E. H. Hogg, R. J. Hall, and E. Arsenault. 2010. Massive mortality of aspen following severe drought along the southern edge of the Canadian boreal forest. Global Change Biology 17: 2084-2094.

Moss, E. H., and J. A. Campbell. 1947. The fescue grassland of Alberta. Canadian Journal of Research 25 (section C): 209-227.

Mueggler, W. F. 1989. Age distribution and reproduction of Intermountain Aspen stands. Western Journal of Applied Forestry 4: 41-45.

Pylypec, B., and J. T. Romo. 2003. Long-term effects of burning Festuca and Stipa-Agropyron grasslands. Journal of Range Management 56: 640-645.

R Development Core Team. 2011. R: A language and environment for statistical computing. R Foundation for Statistical Computing, Vienna, Austria. http://www.R-project .org.

Ripley, E. A., and O. W. Archibold. 1999. Effects of burning on prairie aspen grove microclimate. Agriculture, Ecosystems \& Environment 72: 227-237.

Romo, J. T. 2003. Reintroducing fire for conservation of fescue prairie association remnants in the northern Great Plains. Canadian Field Naturalist 117: 89-99.

Schier, G. A. 1973. Origin and development of Aspen root suckers. Canadian Journal of Forest Research 3: 45-53.

Seager, S. T., C. Eisenberg, and S. B. St. Clair. In press. Patterns and consequences of ungulate herbivory on aspen in western North America. Forest Ecology and Management.

Trottier, G. C. 1985. Evaluation of the prescribed burn study, Prince Albert National Park. Canadian Wildlife Service Report, Edmonton, Alberta.

Weir, J. M. H. 1996. The fire frequency and age mosaic of a mixedwood boreal forest. M.Sc. thesis, University of Calgary, Calgary, Alberta.

Received 13 March 2013

Accepted 3 May 2013 